\title{
Marketing Efficiency and Post Harvest Loss of Flower in Bangladesh
}

\author{
Md. Imran Omar ${ }^{1}$, Md. Monowarul Islam Chowdhury² \& Md.Tauhidul Islam², \\ Md.Rauful Islam ${ }^{3}$, Mohaiminul Islam ${ }^{4}$ \\ ${ }^{1 \& 2}$ Scientific officer, Agricultural Economics Division, Bangladesh Agricultural Research Institute, Joydevpur, \\ Gazipur-1701. \\ ${ }^{2}$ Scientific officer, Barind Station, OFRD, Bangladesh Agricultural Research Institute, Joydevpur, Gazipur- \\ $1701 \&{ }^{2}$ Scientific officer, Agronomy Division, Bangladesh Institute of Nuclear Agriculture (BINA), \\ Mymensingh. \\ ${ }^{3 \& 4}$ Post Graduate Student of Agriculture Faculty, Bangladesh Agricultural University, Mymensingh-2202.
}

\begin{abstract}
The present study was conducted to estimate the post harvest losses of flower and its impact on farmer's net profit, marketing margin and marketing efficiency and also estimate producer's share in consumer's price at different level of marketing such as producer, local trader, wholesaler and retailer. Primary data were randomly collected from 110 respondents from Jessore and Dhaka city. The study covered four kinds of flower such a rose (White), marigold, Jasmine (Yellow) and Tulip (Purple). Post harvest losses was highest at retail level (39.82\%) followed by wholesaler (27.52\%), producer (18.87\%) and local trader (13.78\%) per hundred of all flowers. Due to post harvest losses the marketing margin of the local traders, wholesaler and retailers decreased by 6.14, 8.88 and 7.65 per cent respectively. Total marketing margin was reduced due to post harvest loss for Rose (White), marigold, Jasmine (Yellow)and Tulip (Purple) by 12.16, 62.55, 3.83 and 17 per cent respectively. Tulip (Purple) market was more efficient than other flowers market in both with and without post harvest loss. Producer's share in consumer's taka in the present study was comparatively lower. Lack of storage facilities, inadequate and under developed transportation and communication system, absence of scientific and modern harvesting technology, lack of infrastructural facilities and standardized packing method are the main reason which deteriorate the quality of flower and enhance the post harvest losses of flower. Some measures are suggested for reducing post harvest losses of flower.

Keywords: Marketing Margin, Marketing Efficiency, Post Harvest Loss, Producer's Share.
\end{abstract}

\section{Introduction}

The flower farming is an important and profitable enterprise in the Agriculture sector of Bangladesh. The area under floriculture is increasing day by day, particularly in the area adjacent to big cities. In fact flower farming is labor intensive as compared to other Horticulture crops particularly vegetables rather, it lies in between the two ends with the skilled labor force and modern techniques, it has been proved that the investment in this sector yields high returns for the growers. It is evident from the increase number of nurseries, green houses, flower markets and flower auction centers and the production of flowers turn out to be about 8000 to 10,000 tons per annum (BBS, 2008, Govt. of Bangladesh). In ornamental plants, especially those that have scented flowers or leaves have essential oil; few are used commercially in perfumes, flavor or cosmetic industries. In all the perfumes used in the world today, oil of rose and jasmine are the most delicate perfumes used since the beginning of human civilization. Although it is very difficult to give exact figures of rose oil production, it is estimated that about ten tones of rose oil produced the world today, of which Bulgaria produces more than five tones followed by Turkey and Morocco (K.L. Chadha et al June,1992). In Bangladesh, rose water is prepared from roses. Rose water is extensively used in flavoring foods, confectionery and funeral ceremonies. While the word Jasmine comes from Arabic word, "Yasmine". Although there are several species of Jasmine that have scented flowers and which are used for making garlands and Attars. Flowers have become symbol of sentiments and an essential part of religious and social ceremonies. Commercial production of flower in Bangladesh started from mid 1980 S at Jessore district. Now around 10,000 hectares are under flower cultivation (Siddika, 2004).The major production is concentrated at Godkhali in Jessore which covered about 60 per cent of total flower production. At present approximately 8000 farmers are engaged in floriculture (Mou, 2006). Due to the varied agro-climatic conditions and relatively low cost of production, Bangladesh has immense opportunities not only to meet the local demands of both traditional and cut flowers but also a high potential for export. Lack of enterprise, technical know-how, standardized methods of growing and harvesting of ornamental flowers of internationally acceptable quality, problem of packing and transportation has been a major impediment in realizing this goal. Farmers involve highly in floriculture practice as it is more profitable than other crop and the demand for flower has been increasing day by day. As a result, there exists a 
competition of high qualityflowerproduction. Production areas are concentrated in the rural environments, but the consumption is concentrated in the cities. There is no organization or association for marketing and distribution of flowers. The flowers, being highly perishable, require special post harvest management. But improved post harvest handling has not yet been initiated in Bangladesh. Inefficient postharvest management deteriorates the quality of flower and as aresult farmers are deprived of getting expected price of flower. So the quality management of flower is of utmost important of getting higher returns. Lack of modern harvesting technology, improper storage, transportation, handling and packing causes both qualitative and quantitative loss of flower.

\section{Post Harvest Loss}

Post harvest loss is the loss that occurs from the point of harvest of flower in the field till it reaches to the hands of ultimate users. Post harvest loss (PHL) of flower occurs at different levels due to different reasons. Flowers are damaged at different levels due to various causes such as over-maturing due to delay in harvesting, plucking and assembling, packing, press due to wholesaling process, loading and unloading, cleaning and sorting, multiple handling and transportation, making flower vase and unsold stock. At retail level post harvest loss is also occurred due to sun and rain because most of the retailer's shop is not well furnished and for this sun and rain deteriorate the quality of flower and as result price of flower becomes low. Keeping in view the abovementioned fact, present study was conducted with the following specific objectives:

\$ To estimate the post harvest loss of selected flower at different stages of handling of the produce

* To analysis the impact of post harvest losses of flower on farmer's net price, marketing margin and marketing efficiency

* To estimate the producer share in consumer's price

\# To identify the major constraints and suggest measures for reducing post harvest loss of flower.

\section{Sampling and Data Collection}

\section{Materials and Methods}

Jessore district is considered as one of the leading flower producing zones in Bangladesh. Two unions, namely Godkhali and Panisaraunder Keshabpur Upazila of Jessore district were selected as the flower growing area while Dhaka city was selected as the consuming centre because it would provide maximum information about flower marketing in Bangladesh. The sample size was 110 of which five were input suppliers, 30 flower growers, and 35 traders 'at local, district and Dhaka city, and another 40 retailers in Dhaka city. Thus the total sample size was 110 which were selected randomly. The primary data were collected by the personal interview method with the help of well-designed and pre-tested schedules. The survey was conducted during January to February in the year of 2009. The study included four kinds of flowers such as Rose (White), marigold, Jasmine (Yellow)and Tulip (Purple)which are commercially producedby the farmers in the study area.

\section{Analytical Procedure}

Net price received by farmer is expressed by the following formula

Where,

$\mathrm{NPF}=\mathrm{GPF}-\mathrm{CF}-(\mathrm{LF} \times \mathrm{GPF})$

$\mathrm{NPF}=$ Net price received by farmers (Tk per100 flowers), GPF $=$ Gross price or price received by farmers (Tkper100 flowers), $\quad$ CF $=$ Marketing cost of farmers (Tk per 100 flowers) and LF = Physical loss of flower (number)

\section{Total Marketing Cost}

Total marketing cost (MC) incurred by producer and by intermediaries was calculated by using the following formula:

Where,

$\mathrm{MC}=\mathrm{CF}+\mathrm{CL}+\mathrm{CW}+\mathrm{CR}$

$\mathrm{CF}=$ Marketing cost of farmer (Tk per 100 flowers), $\mathrm{CL}=$ Marketing cost of local trader (Tk per 100 flowers), $\mathrm{CW}=$ Marketing cost of wholesaler (Tk per 100 flowers) and CR = Marketing cost of retailer (Tk per 100 flowers)

\section{Measurement of Marketing Efficiency}

To examine the marketing efficiency Acharya's method was used (Acharya and Agarwal, 1999). Acharya has modified the formula of estimating marketing efficiency, which is worked out as:

$\mathrm{ME}=\mathrm{FP} /(\mathrm{MC}+\mathrm{MM})$ (before post harvest loss)

$\mathrm{ME}=\mathrm{FP} /(\mathrm{MC}+\mathrm{MM}+\mathrm{ML})($ after post harvest loss $)$

Where, 
$\mathrm{ME}=$ marketing efficiency, $\mathrm{FP}=$ Net price received by the farmer, $\mathrm{MC}=$ Total marketing cost, $\mathrm{MM}=$ Total net margins of intermediaries, $\mathrm{ML}=$ Total marketing loss

Gross margin

Gross Margin $=$ Sale price - Purchase price

Net marketing margin

Net marketing margin $=$ Gross margin - Marketing cost

Producer's Share in Consumer's Price

This was the percentage of the net price received by the producer to the price paid by the consumer or selling price of retailer. It may be expressed as follows: Post Harvest Loss of Flower and its Impacts on Flower

Marketing in Bangladesh

$\mathrm{Ps}=(\mathrm{Pf} \div \mathrm{Pc}) \times 100$

Where, $\mathrm{Ps}=$ Producer's share, $\mathrm{Pf}=$ Net price received by producerand

$\mathrm{Pc}=$ Price paid by consumer

\section{Results and Discussion}

\section{Estimation of Post Harvest Losses at Different Levels forDifferent Flowers}

The post harvest loss at different stages of marketing for different flowers was estimated and it was presented in Table 1. The result revealed that the total post harvest loss at producer level for per hundred of all flowers was 18.87 per cent, of which highest percentage was due to over maturing followed by due to delay in harvesting $(8.13 \%)$ followed by losses due to plucking and assembling $(5.72 \%)$, losses due to transportation, loading and unloading (4.94\%). The major cause of post harvest loss at local trader level was due to press due to wholesaling process $(5.77 \%)$ followed by poor packing $(3.64 \%)$ and transportation $(2.35 \%)$ and cleaning and sorting (2.13\%). Thus 13.78 per cent of total post harvest loss on value basis was occurred at local trader level. Total post harvest losses were 27.52 percent at wholesale level. The causes of loss were transportation $(9.2 \%)$, loading and unloading (7.23\%), packing (5.82\%) and unsold stock (5.27\%). The maximum loss was occurred at retail level which accounted 39.82 per cent of total post harvest loss. The causal factors were identified as unsold stock (17.4\%), during making flower vase $(9.86 \%)$, and multiple handling and transportation $(6.86 \%)$ and processing for sale $(5.81 \%)$. In addition, most of the retailer's flower shop is not well shaded and retailer retains the flowers for a longer period than others, so sun and rain easily deteriorate the unsold flowers and retailer also perform more processing activities than other functionaries such as making flower vase, cleaning, sorting, some time change the form of the flower.

Table 1: Post harvest loss at different levels for different flowers

\begin{tabular}{|c|c|c|c|c|c|}
\hline Particulars & $\begin{array}{c}\text { Rose } \\
\text { (White) } \\
\end{array}$ & Marigold & $\begin{array}{c}\text { Tulip } \\
\text { (Purple) }\end{array}$ & $\begin{array}{l}\text { Jasmine } \\
\text { (Yellow) }\end{array}$ & Total \\
\hline \multicolumn{6}{|l|}{ 1. Local traders } \\
\hline a. Sales price (GPT) & 165 & 9.2 & 439 & 97 & 710 \\
\hline b. Purchase price (GPF) & 100 & 6.8 & 269 & 65 & 440.8 \\
\hline c. Marketing cost (CT) & 11.75 & 1.34 & 17.91 & 17.25 & 48.25 \\
\hline d. Marketing margin (before) & 53.25 & 1.06 & 152.09 & 14.75 & 221.15 \\
\hline e. Loss of flower in value (--LT×GPT) & 4.9 & 0.82 & 5.52 & 2.32 & 13.57 \\
\hline f. Net marketing margin (after) & 48.34 & 0.24 & 146.57 & 12.56 & 207.71 \\
\hline \multicolumn{6}{|l|}{ 2. Wholesaler 0.00} \\
\hline a. Sales price (GPW) & 255 & 9.95 & 645 & 111.02 & 1020.97 \\
\hline b. Purchase price (GPT) & 160 & 7.6 & 438 & 88 & 693.6 \\
\hline c. Marketing cost $(\mathrm{CW})$ & 6.07 & 0.56 & 6.48 & 3.15 & 16.26 \\
\hline d. Net marketing margin (before) & 81.93 & 1.71 & 201.52 & 19.87 & 305.03 \\
\hline e. Loss of flower in value $(\mathrm{LW} \times \mathrm{GPW})$ & 15.23 & 0.68 & 6.94 & 4.25 & 27.1 \\
\hline f. Net marketing margin (after) & 73.7 & 1.11 & 193.58 & 15.62 & 284.01 \\
\hline \multicolumn{6}{|l|}{ 3. Retailer 0.00} \\
\hline a. Sales price (GPW) & 428 & 20.7 & 915 & 155 & 1518.7 \\
\hline b. Purchase price (GPR) & 248 & 9.35 & 535.5 & 95.5 & 888.35 \\
\hline c. Marketing cost (CR) & 36.52 & 4.44 & 47.2 & 28.76 & 116.92 \\
\hline d. Net marketing margin (before) & 143.48 & 5.91 & 332.3 & 30.74 & 512.43 \\
\hline
\end{tabular}




\begin{tabular}{lccccc} 
e. Loss of flower in value (LR.×GPR) & 20.75 & 4.01 & 9.75 & 4.7 & 39.21 \\
f. Net marketing margin (after) & 122.73 & 1.9 & 322.55 & 26.04 & 473.22 \\
\hline 4. Total marketing margin of intermediaries (before) & 278.66 & 8.68 & 685.91 & 65.36 & 1038.61 \\
5. Total marketing margin of intermediaries (after) & 244.77 & 3.25 & 662.7 & 54.22 & 964.94 \\
6. Per cent change & 12.16 & 62.55 & 3.83 & 17.04 \\
\hline
\end{tabular}

\section{Impact of Post Harvest Loss on Farmer's Net Price,}

\section{Marketing Margin and Marketing Efficiency}

Net price received by farmer was estimated as the difference ingross price received by farmer and sum of the marketing cost andvalue loss during harvesting, loading and unloading and marketingof flower. Per hectare net price received by farmer is presented inTable 2 . The result revealed that the flower production was profitablein the study area. Jasmine (Yellow) production was more profitable forfarmer than other flowers. The farmer received highest net priceper hectare from Jasmine (Yellow) (Tk. 663601.29) followed by Rose (White) (Tk. 544452.6), Tulip (Purple) (Tk. 308245.4) and marigold (Tk. 18364.5) before excluding post harvest loss.

Table 2: Per hectare net price received by farmers

\begin{tabular}{lcccc}
\hline Particulars & Rose (White) & Marigold & Jasmine (Yellow) & Tulip (Purple) \\
\hline Gross price (GPF) (Tk) & 586000 & 217940 & 691733.5 & 334490 \\
Marketing cost (CF) (Tk) & 41547.4 & 34293.5 & 28132.21 & 26244.6 \\
Net price (Tk) (before) & 544452.6 & 183646.5 & 663601.3 & 308245.4 \\
Loss of flower in value (LF×GPF) (Tk) & 33870.8 & 70830.5 & 18489.08 & 17033.26 \\
Net price (Tk) (after) & 510581 & 112816 & 645112.2 & 291212.1 \\
Percentage change & 6.22 & 38.57 & 2.79 & 5.53 \\
\hline
\end{tabular}

It is apparent from Table 2 that netprice received by farmer after deducting post harvest loss for Rose (White),marigold, Jasmine (Yellow) and Tulip (Purple) were reduced by $6.22 \%, 39.56 \%, 2.79 \%$ and $5.53 \%$ respectively.

\section{Marketing Margin}

The intermediaries net marketing margin were worked out with and without taking into account the post harvest loss and results are presented in Table 3. It is seen from the table that marketing margin was reduced due to post harvest loss for Rose (White), marigold, Jasmine (Yellow) and Tulip (Purple) by 12.16, $62.55,3.83$ and 17.04 per cent respectively.

Table 3: Net marketing margin of intermediaries before and after excluding post harvest loss Tk. per 100 flowers

\begin{tabular}{|c|c|c|c|c|c|c|c|c|c|}
\hline \multirow[b]{2}{*}{ Particulars } & \multicolumn{2}{|c|}{ Rose (White) } & \multicolumn{2}{|c|}{ Marigold } & \multicolumn{2}{|c|}{ Tulip (Purple) } & \multicolumn{2}{|c|}{ Jasmine (Yellow) } & \multirow{2}{*}{$\begin{array}{l}\% \text { of } \\
\text { Total } \\
\text { Value }\end{array}$} \\
\hline & $\begin{array}{l}\text { Quantity } \\
\text { (No.) }\end{array}$ & $\begin{array}{l}\text { Value } \\
\text { (Tk) }\end{array}$ & $\begin{array}{l}\text { Quantity } \\
\text { (No.) }\end{array}$ & $\begin{array}{l}\text { Value } \\
\text { (Tk) }\end{array}$ & $\begin{array}{l}\text { Quantity } \\
\text { (No.) }\end{array}$ & $\begin{array}{l}\begin{array}{l}\text { Value } \\
(\mathrm{Tk})\end{array} \\
\end{array}$ & Quantity (No.) & $\begin{array}{l}\text { Value } \\
(\mathrm{Tk})\end{array}$ & \\
\hline 1. Farm level (Total flower) & 100 & 100 & 100 & 6.8 & 100 & 269 & 100 & 65 & 447.7 \\
\hline \multicolumn{10}{|l|}{ Damaged flower due to: } \\
\hline Plucking and assembling & 2.01 & 2.01 & 4.56 & 0.31 & 0.69 & 1.86 & 2.23 & 1.45 & 5.72 \\
\hline $\begin{array}{l}\text { Transportation, loading and } \\
\text { unloading }\end{array}$ & 1.83 & 1.83 & 20.88 & 1.42 & 0.27 & 0.74 & 1.33 & 0.87 & 4.94 \\
\hline $\begin{array}{l}\text { Over-maturing due to delay in } \\
\text { harvesting }\end{array}$ & 1.94 & 1.94 & 7.05 & 0.48 & 1.71 & 4.59 & 1.53 & 0.99 & 8.13 \\
\hline Total damaged flowers (\%) & 5.87 & 5.87 & 32.5 & 2.21 & 2.67 & 7.19 & 5.09 & 3.31 & 18.87 \\
\hline 2. Local trader (Total flower) & 100 & 160 & 100 & 7.6 & 100 & 438 & 100 & 88 & 704.5 \\
\hline \multicolumn{10}{|l|}{ Damaged flower due to: } \\
\hline Press due to wholesaling process & 1.65 & 1.65 & 3.15 & 0.24 & 1.05 & 2.82 & 1.5 & 0.97 & 5.77 \\
\hline Packing & 1.59 & 1.59 & 1.84 & 0.14 & 0.53 & 1.42 & 0.67 & 0.43 & 3.64 \\
\hline Cleaning and sorting & 0.79 & 0.79 & 3.02 & 0.23 & 0.23 & 0.61 & 0.73 & 0.47 & 2.13 \\
\hline Transportation & 0.98 & 0.98 & 2.76 & 0.21 & 0.25 & 0.67 & 0.7 & 0.45 & 2.35 \\
\hline Total damaged flowers (\%) & 4.91 & 4.91 & 1.76 & 0.82 & 2.06 & 5.52 & 3.6 & 2.32 & 13.78 \\
\hline 3. wholesaler (Total flower) & 100 & 160 & 100 & 7.6 & 100 & 438 & 100 & 88 & 704.5 \\
\hline \multicolumn{10}{|l|}{ Damaged flower due to: } \\
\hline Transportation & 2.86 & 4.59 & 2.89 & 0.22 & 0.57 & 2.5 & 1.98 & 1.75 & 9.2 \\
\hline
\end{tabular}


Marketing Efficiency and Post Harvest Loss of Flower in Bangladesh

\begin{tabular}{lccccccccc} 
& & & & & & & & & \\
Loading and unloading & 2.71 & 4.35 & 2.36 & 0.18 & 0.45 & 2 & 0.67 & 0.59 & 7.23 \\
Packing & 2.26 & 3.63 & 2.63 & 0.2 & 0.23 & 1.05 & 0.96 & 0.85 & 5.82 \\
Unsold stock & 1.66 & 2.66 & 1.05 & 0.08 & 0.31 & 1.39 & 1.2 & 1.06 & 5.27 \\
Total damaged flowers (\%) & 9.49 & 15.23 & 8.97 & 0.68 & 1.56 & 6.94 & 4.81 & 4.25 & 27.52 \\
\hline 4. Retailer (Total flower) & 100 & 248 & 100 & 9.35 & 100 & 535.5 & 100 & 95.5 & 902.2 \\
Damaged flower due to: & & & & & & & & & \\
Multiple handling and & 1.74 & 4.32 & 2.99 & 0.28 & 0.45 & 1.9 & 0.26 & 0.25 & 6.86 \\
transportation & 2.67 & 6.63 & 16.04 & 1.5 & 0.24 & 1.08 & 0.52 & 0.5 & 9.86 \\
Making flower vase & 0.78 & 1.95 & 13.15 & 1.23 & 0.28 & 1.09 & 1.52 & 1.45 & 5.81 \\
Processing for sale & 3.16 & 7.85 & 11.76 & 1.1 & 1.25 & 5.68 & 2.63 & 2.5 & 17.4 \\
Unsold losses & 8.35 & 20.75 & 42.88 & 4.01 & 2.22 & 9.75 & 4.93 & 4.73 & 9.82 \\
Total damaged flowers (\%) & 28.62 & 46.76 & 95.08 & 7.72 & 8.51 & 29.4 & 18.43 & 14.58 & 100 \\
\hline Total value of post-harvest loss & & & & & & & & &
\end{tabular}

Post Harvest Loss of Flower and its Impacts on Flower Marketing in Bangladesh Table 4 shows that the retailers captured the highest marketing margins both in before and after deducting post harvest loss followed by wholesalers and local traders. The highest change of marketing margins in per cent was found for wholesalers $(8.88 \%)$ followed by retailer $(7.65 \%)$ and local traders $(6.14 \%)$.

Table 4: Change in marketing margin of different intermediaries

\begin{tabular}{lccc}
\hline \multicolumn{1}{c}{ Particulars } & $\begin{array}{c}\text { Before excluding } \\
\text { post harvest loss }\end{array}$ & $\begin{array}{c}\text { After excluding post } \\
\text { harvest loss }\end{array}$ & $\begin{array}{c}\text { change in Percent } \\
\text { (Decreased) }\end{array}$ \\
\hline Local traders total margin Tk./100 flowers & 221.15 & 207.71 & 6.14 \\
Wholesaler's total margin Tk./100 flowers & 305.03 & 284.01 & 8.88 \\
Retailer's total margin Tk./100 & 512.43 & 473.22 & 7.65 \\
\hline
\end{tabular}

\section{Marketing Efficiency}

Marketing efficiency is essentially the degree of market performance. The term marketing efficiency may be broadly defined as the effectiveness or competence with which a market structure performs its designated function (Jasdanwalla, 1996). Kohls and Uhl (2005, p. 35) defined marketing efficiency as the maximization of input output ratio. An efficient marketing system is an effective means of change and an important way of raising the income levels of the farmer and the levels of satisfaction of the consumers. Efficient marketing system plays an important role not only in stimulating production but also in accelerating the pace of economicdevelopment. The marketing efficiency before excluding post harvest loss for Rose (White), marigold, Jasmine (Yellow) and Tulip (Purple) was 0.25, 0.29, 0.32 and 0.46 respectively. The marketing efficiency after excluding post harvest loss for Rose (White), marigold, Jasmine (Yellow)and Tulip (Purple)was 0.22, 0.20, 0.310 .41 respectively (Table 5). Theoretically it is revealed from Table 5 that Tulip (Purple) flower market was more efficient than other flowers market.

Table 5: Marketing efficiency of market intermediaries before and after excluding post harvest loss

\begin{tabular}{lcccc}
\multicolumn{1}{c}{ Particulars } & $\begin{array}{c}\text { Rose } \\
\text { (White) }\end{array}$ & Marigold & $\begin{array}{c}\text { Jasmine } \\
\text { (Yellow) }\end{array}$ & Tulip (Purple) \\
\hline Farmers net price NP (Tk/100 flowers) & 85.82 & 4.66 & 247.12 & 54.8 \\
Total marketing margin MM (Tk/100 flowers) & 278.66 & 8.68 & 685.91 & 65.36 \\
Total marketing cost MC (Tk/100 flowers) & 61.43 & 7.41 & 82.53 & 54.26 \\
Total marketing loss ML(Tk/100 flowers) & 46.67 & 7.72 & 29.4 & 14.58 \\
Marketing efficiency (before) & 0.25 & 0.29 & 0.32 & 0.46 \\
Marketing efficiency (after) & 0.22 & 0.2 & 0.31 & 0.41 \\
\hline
\end{tabular}

\section{Producer's Share in Consumer's Price}

Table 6 represented that the price paid by consumer for per hundred of Rose (White) was calculated Tk. 428 which was Tk. 20.70 for marigold and Tk. 815 for Jasmine (Yellow) and Tk. 155 for Tulip (Purple). Table 6 shows that the producer's share in consumer's price for Rose (White), marigold, Jasmine (Yellow)and Tulip (Purple) was 20.05\%, 22.51\%, 30.32\% and 35.35\% per hundred flowers respectively before excluding post harvest loss, while after excluding post harvest loss the corresponding shares reduced to $18.7 \% 11.84 \%, 29.44 \%$ and $33.22 \%$.

Table 6: Producer's share in consumer's price 


\begin{tabular}{|c|c|c|c|c|}
\hline Particulars & $\begin{array}{c}\text { Rose } \\
\text { (White) }\end{array}$ & Marigold & $\begin{array}{l}\text { Jasmine } \\
\text { (Yellow) }\end{array}$ & Tulip (Purple) \\
\hline \multicolumn{5}{|l|}{ A. Before excluding post harvest loss } \\
\hline Net price received by farmers(Tk/100 flowers) & 85.82 & 4.66 & 247.12 & 54.8 \\
\hline Price paid by consumer (Tk/100flowers) & 428 & 20.7 & 815 & 155 \\
\hline Producer's share in consumer price ( $\mathrm{Tk} / 100 \mathrm{flowers})$ & 20.05 & 22.51 & 30.32 & 35.35 \\
\hline Price spread & 342.18 & 16.04 & 567.88 & 100.2 \\
\hline \multicolumn{5}{|l|}{ B. After excluding post harvest loss } \\
\hline Net price received by farmers(Tk/100 flowers) & 80 & 2.45 & 239.93 & 51.49 \\
\hline Price paid by consumer (Tk/100flowers) & 428 & 20.7 & 815 & 155 \\
\hline Producer's share in consumer price ( $\mathrm{Tk} / 100 \mathrm{flowers})$ & 18.7 & 11.84 & 29.44 & 33.22 \\
\hline Price spread & 347.96 & 18.25 & 575.07 & 103.51 \\
\hline
\end{tabular}

Price spread for per hundred of Rose (White), marigold, Jasmine (Yellow)and Tulip (Purple)was Tk. 342.18, Tk. 16.04, Tk. 567.88 and Tk. 100.2 before excluding post harvest loss, which was Tk. 347.96, Tk. 18.25, Tk.575.07 and Tk. 103.51 after excluding post harvest loss. It is apparent from the table that producer's share in consumer's taka was comparatively lower which ranged from $20 \%$ to $35 \%$ before excluding post harvest loss. After deducting post harvest loss, the producer's share in consumer's taka varied from about $12 \%$ to $33 \%$.

\section{Major Problems Relating to Post Harvest Loss (PHL)}

The flower grower in the study area faced number of problems in post harvest management, which are required to be addressed to ensure their economic prosperity. Major problems relating to postharvest loss of different flowers are described below:

\section{Scientific Storage Methods}

Being perishable in nature, flowers have to be harvested as soon as they get matured, otherwise their quality get deteriorated. There are no storage facilities for flower in Bangladesh. Though processing center is established in Godkhali, but it is not working properly and it is very expensive for trader to use it. Due to lack of storage facility in majority of the wholesale market, farmers were forced to sell their produce on the same day even if the prices wereruling very low.

\section{Inadequate and Under Developed Transportation and Communication system}

Farmers in the study area are still using the age old means of transportation like hand cart and cycle van which were being pulled by human beings. Flower produced in the study area is mostly marketed to Dhaka which is so far from there. Wholesaler used the bus service for transporting flower from Godkhali to Dhaka. There is no special vehicle for transporting flower. The existing transportation system deteriorates the quality of flower. So inadequate and under developed transportation and communication system is an important reason for post harvest losses of flower.

\section{Inadequate Infrastructure Facilities}

There is no well-shed to protect farmer and flower from rain or sun. Most of the time farmers had to sell their flower standing in the open place. So lack of infrastructure such as puce floor, tin shed, drainage, water supply etc. was the problems which increase the post harvest loss.

\section{Packing Method}

The traditional packing method with rope and plastic was considered inadequate for long transportation. But this type of packing method is followed in the study area. It also reduces the quality of flower.

\section{Modern Harvesting Technologies}

Flower is highly perishable and requires special kind of postharvest handling. Commercial flower farming is a new practice in Bangladesh. Farmers use the traditional method of harvesting. It deteriorates the quality of flower. It causes the loss at post harvest. There is a shortage of trained manpower to handle commercial floriculture activities such as production, post harvest handling and biotechnology.

\section{Conclusion and Recommendations}

With the increased demand for flower, there is ample opportunity for increasing the profit from flower production. But post harvest losses affected the profit of flower grower Income from floriculture has a remarkable contribution to increase total household income. The share of floriculture to household income increased from zero to 24.47 per cent which have a positive impact on increasing total household income. For small, medium and large farmers, income from different sources was also increased than before situation of 
practicing commercial floricultural. Hence, commercial floriculture has a remarkable positive impact on increasing total household income (Yeasmin, 2009). Therefore, the following measures are required to be undertaken for ensuring the economic prosperity for the flower grower:

$>$ Flower storage facilities should be established by the government initiative. Government may take measure toprovide loan to the private sector so that they would come to establish the storage facilities.

$>$ Training on scientific production practices, harvesting technology of flowers along with other post harvest activities should be imparted to the flower growers and the marketing intermediaries.

$>$ Floriculture research should be given more importance and Government assistance in research and development is to be needed.

$>$ Government should help in providing air-conditioned freezer van for the transportation of flower from production area to market places of different districts.

$>$ The infrastructure facilities of the flower market should be developed.

$>$ For the development of post harvest infrastructure and other facilities attempts should be undertaken through public, private and also public-private partnership basis.

$>$ Flower growers should be organized into group which will enhance their bargaining power and also improve their productivity. Post harvest loss will also be reduced due to better handling of flower.

\section{References}

[1]. Acharya, S.S. and N.L. Agarwal, 1999. Agricultural Marketingin India. Oxford and IBH Publishing Co., PVT., Ltd., NewDelhi.

[2]. Bagchi, Mita, 2009. Supply Chain Analysis of Flower in Jessoreand Dhaka Districts, MS thesis Submitted to the

[3]. Department of Agribusiness and Marketing, Bangladesh Agricultural University, Mymensingh Bangladesh.

[4]. printed in india 211Post Harvest Loss of Flower and its Impacts on Flower Marketing in Bangladesh

[5]. Jasdanwalla, Z.Y. 1966. Marketing Efficiency in IndianAgriculture. Allied Publishers Private Limited, New Delhi.

[6]. Kohls, R.L. and J.N. Uhl, 2005. Marketing of AgriculturalProducts (fifth edition). Prentice Hall of India Private

[7]. Limited, New Delhi.

[8]. Kumar, N.R. Pundy, N.K. and Rana, R.K. 2008. Marketing andPost-harvest losses of Cabbage and Couliflower in WestBengal, Indian Journal of Agricultural Marketing,22 (3): 25-37.

[9]. Mou, N.H. 2006. An Economic Study on Commercial Productionand Marketing of Flower in Bangladesh. M .S. Thesis,Department of Agricultural Economics, BangladeshAgricultural University, Mymensingh Bangladesh.

[10]. Siddika, M. 2004. Marketing of Commercial Cut-Flower inBangladesh. M. S. Thesis, Department of Co-operationand Marketing, Bangladesh Agricultural University,Mymensingh. Bangladesh.

[11]. Yeasmin, S. 2009. Socioeconomic Impact of CommercialFloriculture on Improving Livelihood of FarmHouseholds in Selected Areas of Jessore District. M.S.Thesis, Department of Agricultural Economics,Bangladesh Agricultural University, Mymensingh.Bangladesh. 